\title{
Ethics in Teaching Profession
}

\author{
Mahbuba Sultana
}

Lecturer in Management, Northern University Bangladesh, BANGLADESH

\begin{abstract}
Ethics is the most concerning issues now a day. The society is becoming corrupted and youth generations are doing unethical activities randomly. Family plays an important role to make the children ethical, but teacher has a great role too regarding this issue. A teacher can raise the morality of a student by encouraging the ethical practices. This paper tried to focus on what is ethics and what is the relation of ethics with the teaching profession and finally tried to recommend a code of ethics for teachers.
\end{abstract}

Keywords: Ethics, Code of Ethics, Teacher, Teaching Profession

\section{INTRODUCTION}

In recent years awareness regarding ethical aspects has been increase in the general people. When an occupation organizes itself as a profession, a code of ethics appears. Educational ethics apply to those professionals that are active within education. Ethics is a branch of philosophy concerned with the study of what is good and bad. Ethical behavior is the way a living creature acts. A teacher's work covers many things and ethics is one of them.

According to Moral agency and ethical knowledge, ethics in teaching is the practice of ethical codes and a formal perception of behavior and relevant disposition of the teacher. Ethics consider as one of the elements of human virtue through attitude, intentions, words and actions. It is the realization of good and identifies the bad which they apply in everyday practice of teachers as a professional individual and group. Ethics focus on honesty and fairness which teachers are actually going to imply on teaching profession (Moral agency and ethical knowledge).A teacher has to contextualize in classroom with own morale disposition problems and uncertainties. Ethics reflect the implications of what a teacher say or do and do not do not only in critical and confusing situation but also in their routine class time.

\section{What IS ETHICS}

Ethics, also known as moral philosophy, is a branch of philosophy that involves systematizing, defending, and recommending concepts of right and wrong conduct. The term comes from the Greek word ethos, which means "character".

Ethics is a complement to Aesthetics in the philosophy field of Axiology. In philosophy, ethics studies the moral behavior in humans, and how one should act.

According to Tomas Paul and Linda Elder of the Foundation for Critical Thinking, "most people confuse ethics with behaving in accordance with social conventions, religious beliefs, and the law", and don't treat ethics as a stand-alone concept. 
Paul and Elder define ethics as "a set of concepts and principles that guide us in determining what behavior helps or harms sentient creatures". The Cambridge Dictionary of Philosophy states that the word ethics is "commonly used interchangeably with 'morality' ... and sometimes it is used more narrowly to mean the moral principles of a particular tradition, group, or individual."

\section{What is Professional Ethics}

Professional people and those working in acknowledged professions exercise specialist knowledge and skill. How the use of this knowledge should be governed when providing a service to the public can be considered a moral issue and is termed professional ethics.

Professionals are capable of making judgments, applying their skills and reaching informed decisions in situations that the general public cannot, because they have not received the relevant training. Professional ethics is a set of standards adopted by a professional community. Professional ethics are regulated by standards, which are often referred to as codes of ethics.

The code of ethics is very important because it gives us boundaries that we have to stay within in our professional careers. The one problem with the code of ethics is that we can't always have the answers in black and white. Sometimes there are grey areas where the answers aren't so simple. Professional ethics are also known as Ethical Business Practices.

Components: A number of professional organizations define their ethical approach as a number of discrete components. Typically these include:

$\checkmark$ Honesty,

$\checkmark$ Integrity,

$\checkmark$ Transparency,

$\checkmark$ Accountability,

$\checkmark$ Confidentiality,

$\checkmark$ Objectivity,

$\checkmark$ Respectfulness, and

$\checkmark$ Obedience to the law

A professional ethics course is not about disseminate virtue to raise morality among immoral and amoral students, it also the ability to concern the respective citizens to first recognize and then responsibly confront moral issues.

\section{Code of Ethics and Professional Conduct}

Code of ethics is a written set of guidelines issued by an organization to itsworkers and management to help them conduct their actions in accordance with its primary values and ethical standards.

Code of ethics also can be defined that a guide of principles designed to help professionals conduct business honestly and with integrity. A code of ethics document may outline the mission and values of the business or organization, how professionals are supposed to approach problems, the ethical principles based on the organization's core values and the standards to which the professional will be held.

Codes of ethics give consent of the profession on ethical issues. Codes of ethics at a time educate the general people about the ethical norms and values of profession. A code of ethics should be considered as conventions between professionals. Having a code of ethics allows a professional to object to pressure to produce standard work not only bind in 
moral agent but also as a professional. Davis (1991) said that "as a professional, I cannot ethically put business concerns ahead of professional ethics."

Harris (1995) summarized in his analysis that code of ethics first serve as a collective recognition by members for its responsibility. Second, it helps to create the environment where ethical behavior is a norm. Third, it can act as a guide in many situations. Fourth, process of developing and modifying the code of ethics help in profession. Fifth, it acts as an educational tool to give focus point in classes and meetings. Finally, it indicates others that the profession is concern about responsible and professional conduct.

\section{Ethics and Teaching Profession}

Teachers work cover many things and ethics is one of them. Burger 1999 discussed in his speech that education has three goals: 1. Get Value, 2. Get Knowledge and 3. Acquire Skills and it is the duty of a teacher to work on the values and morals of our children. Students can learn about values by the day to day living examples of teachers- both in campus and private lives.

John (2004) classified two relevant aspects of teaching: 1. Ethics in teaching and 2. Deal with academic commitment. A teacher should know about ethics and the ethics in teaching:

1. Code of ethics and ethical norms

2. Understanding teacher-student relationship

3. Tension in teacher-student relationship

4. Pedagogical issues

One valuable source of information about ethical teaching is an issue of New Directions for Teaching and Learning. The editor produced a special edition of the journal, titled Ethical Dimensions of College and University Teaching: Understanding and Honoring the Special Relationship Between Teachers and Students, in which several authors provided theoretical and practical guidelines for honing ethical college teaching skills. Some of the authors' recommendations are listed below.

\section{Four Norms to Govern Teaching}

- Honesty

- Promise-Keeping: Promise-keeping requires the instructor to fulfill the "promises" made at the beginning of the semester. Syllabi, assignments, grading principles, and class and office hour schedules involve promises made to students.

- Respect for Persons: Teachers ought to encourage mutual respect among students. Additionally, instructors ought to show respect and common courtesy for students both during interpersonal interactions and in responding promptly to students' need for guidance and feedback.

- Fairness: Recognizing the inherent subjectivity involved in grading, instructors ought to ensure that their grading practices are as objective as possible by creating and adhering to unambiguous criteria.

\section{Principles of Ethical College and University Teaching}

1. Content Competence - A university teacher maintains a high level of subject matter knowledge and ensures that course content is current, accurate, representative, and appropriate to the position of the course within the student's program of study.

2. Pedagogical Competence - A pedagogically competent teacher communicates the objectives of the course to students, is aware of alternative instructional methods or strategies, and selects methods of instruction that are effective in helping students to achieve the course objectives. 
3. Dealing with Sensitive Topics - Topics those students are likely to find sensitive or discomforting are dealt with in an open, honest, and positive way.

4. Student Development - The overriding responsibility of the teacher is to contribute to the intellect development of the student, at least in the context of the teacher's own area of expertise, and to avoid actions such as exploitation and discrimination that detract from student development.

5. Dual Relationships with Students - To avoid conflict of interest, a teacher does not enter into dual-role relationships with students that are likely to detract from student development or lead to actual or perceived favoritism on the part of the teacher.

6. Confidentiality - Student grades, attendance records, and private communications are treated as confidential materials and are released only with student consent, for legitimate academic purposes, or if there are reasonable grounds for believing that releasing such information will be beneficial to the student or will prevent harm to others.

7. Respect for Colleagues - A university teacher respects the dignity of her or his colleagues and works cooperatively with colleagues in the interest of fostering student development.

8. Valid Assessment of Students - Given the importance of assessment of student performance in university teaching and in students' lives and careers, instructors are responsible for taking adequate steps to ensure that assessment of students is valid, open, fair, and congruent with course objectives.

9. Respect for Institution - In the interest of student development, a university teacher is aware of and respects the educational goals, policies, and standards of the institution in which he or she teaches.Visit the Association for Practical and Professional Ethics' Web site to learn more about ethics in college teaching.

\section{IMPORTANCE OF THE ETHICS IN TEACHING}

The code of ethics for teachers is designed to protect the rights of the students, all the students. It is important that teachers understand that when they get a teaching position they are agreeing to follow the code of ethics.

Teachers are expected to be fair to all their students and not to take advantage of their position in any way. For example, teacher can't accept expensive gifts from students because it might appear to bias. Teacher can't push their personal beliefs on students because they are a "captive audience". Teacher need to have a professional relationship with all students and not let it get too casual and familiar. Apparently, there is quite a bit of abuse that is happening in the school. Teacher need to protect his/her students' safety and not believe that this is someone else's job. The main thing is not to abuse the power that the position, over the students, might give the teacher.

Caetano and Silva (2009) explained in their research that ethical dimensions are important in our education system and are in several legislative documents, both with regard to the student and teacher and as well as important for professional performance. The ethical issues are associated with social, spiritual, moral and civic values. And it is the teacher who can give a right direction to the student to raise their morality.

Ethical issues arise when there are differences of judgment or expectations about what a proper course of action. An individual makes the ethical decision as a member of different groups. When an individual faced with a dilemma, a professional must be able to take rational and well motivated decisions and in this case the code of ethics help the individual by providing tools and methods suitable in such situations. 
John Clark (2004) in his paper discussed that for teachers ethics is more than code of ethics which is the set of principles and rules which serve in disciplinary processes. Teachers as a professionals are responsible in one of the most ethically demanding jobs, to provide education in young people. It is teachers' duty to reflect on their activities to make sure the best ethical example to those who are educating morally.

A teacher has to play various roles both inside and outside of classroom. Teacher can develop the morality among the student by setting the examples of their ethical behavior. Ethics and morals are often associated with religion, but schools can also provide important lessons in ethical thinking and action.

"There's a big fear out there that somehow teaching ethics in school will seep into students a particular religious viewpoint," says Dr. Bruce Weinstein, aka The Ethics Guy. "But ethics must be taught and are being taught in school. It's impossible not to teach ethics in a school."

Weinstein, who writes a weekly column for BusinessWeek.com and recently released the popular book Is It Still Cheating if I Don't Get Caught?, says if schools have a code of conduct, they are teaching ethics.

Teachers are essential to preaching these values and ethics towards students. According to Weinstein, there are five basic principles of ethics that are common to all faiths:

- Do no harm

- Make things better

- Respect others

- Be fair

- Be loving.

These values are defined differently in different parts of the world, but they are crosscultural and expected among all groups of people. And Weinstein says they should extend beyond the walls of the sanctuary and should be taught and expected in homes and classrooms as well.

\section{Suggested Code of Ethics for Teachers}

\section{As a Professional Educator:}

Strive to make foremost responsibility the education and welfare of all students in care, and respect the uniqueness and dignity of each student.

Strive to build relationships with students' families, as appropriate, that contribute to students' welfare and education.

Strive to promote mutual respect and trust in relationships with colleagues, assist newcomers to the profession, and behave in a way which enhances the status of the profession.

Do best to fulfill the responsibilities to employer, community and society.

\section{Responsibility toward Students}

Provide learning equally to each student

Recognize students' potentiality

Encourage students' in learning, health and safety

To be fair to each student, justify each student equally

Resolve problem regarding discipline, law and policy. 
Responsibilities toward Parents/Guardians and Families and Community

Establish relationships with parents based on courtesy, mutual trust and open communication.

Respect the privacy of a family.

Share the information with parents regarding the interest of the student.

Respect the family backgrounds of each student.

Play an active role in community relations.

Be truthful to the society.

Provide the standard of professional service.

Develop the values in students of a democratic society.

\section{Commitment to the Professional Colleagues}

Build an atmosphere of trust, mutual respect and openness with the respective colleagues.

Act accordingly to the educational and wider community which enhances the status of the profession.

Do not reveal confidential information about colleagues unless required by law and policy.

Assist, support and encourage newcomers to the profession.

Do not provide false statement about colleagues.

Do not interfere with colleagues' personal freedom which can violate individual professional integrity.

\section{Responsibilities to Employers}

Be truthful when making statements about qualifications and competencies.

Obey the contractual commitments.

Positively promote the improvement of institutional policies.

Promote cooperation among all agencies and professionals working in the best interests of students and families.

Perform those laws and policies that do not conflict with code of organizational ethics.

Operate all the committee accounts honestly to his/her charge.

Maintain sound mental health, stamina social prudence necessary to perform his/her task.

\section{CONCLUSION}

Teacher has a responsibility to the society and in our society teachers are respected all over. Students usually want to be like their favorite teacher in their personal life. So if the teacher can set example by their ethical behavior, than it will be easy to preaching ethical issues among the students. And if the young generation be aware about ethical issues than the total society and country will be benefited. Therefore as an important part of society teacher should be ethical and they should follow the code of ethics of a teacher and should reflect their ethical behavior to their students.

\section{REFERENCES}

Ana Paula Caetano. Maria de Lurdes Silva, sísifo / educational sciences journal $\cdot$ no. $8 \cdot$ jan/apr 09 issn 1646-6500

Davis, M., (1991), Thinking like an engineer: The place of a Code of Ethics in the practice of a profession", Philosophy and Public Affairs, 20.2 150-167.

Dr L. B. Burger, Speech delivered at Beginner teachers conference: Windhoek College of Education, 5 November 1999 
Gordana Dodig-Crnkovic, Department of Computer Science and Engineering, Mälardalen University Västerås, Sweden

Harris, C. E., Jr., Pritchard M. S. and Rabins M. J., 1995, .Engineering Ethics: Concepts and Cases, Wadsworth Publishing

John Clark,New Zealand Journal Of Teachers' Work, Volume 1, Issue 2, 80-84, 2

Moral agency and ethical knowledge: introduction to ethics in teaching pp. 9-22

\section{Web Sites}

https://www.boundless.com/marketing/social-responsibility-ethics-in-marketing/ethicsoverview/definition-ethics/ Definition of Ethics.

http://en.wikipedia.org/wiki/Ethics Definition of ethics

http://en.wikipedia.org/wiki/Professional_ethics Professional ethics

http:/ / www.investopedia.com/terms/c/code-of-ethics.asp Code of Ethics

http://www.gradsch.psu.edu/facstaff/tethics.html Teaching ethics

http:/ / www.education.com/magazine/article/cheating-ethics/ Code of ethics for teachers

http://www.vbsd.us/policies/pdfs/3.1\%20\%20Ethical\%20Standards\%20for\%20Teachers.pdf Code of ethics for teacher 


\section{Publish Online and Print Version Both}

ISSN Online: 2312-203X 